\title{
The Performance of Teachers in the Digital Era in Improving Learning Quality
}

\author{
Hendrik A.E. Lao ${ }^{1}$, Rasdi Ekosiswoyo², Joko Sutarto ${ }^{3}$, Suwito Eko Pramono ${ }^{4}$ \\ ${ }^{1,2,3,4}$ Graduate School, Universitas Negeri Semarang, Indonesia \\ Corresponding email: hendriklao33@gmail.com
}

\begin{abstract}
The development of the digital world today has become a lifestyle that cannot be separated from technology. Hence, teachers are required to follow the development of existing technology in order to make learning process go well. The purpose of this research is to determine the performance of teachers in the digital era in planning, implementation and evaluation to improve the quality of learning. The research method used was qualitative research method with 12 informants as teacher representatives teaching at 12 State Senior High School in Kupang City - East Nusa Tenggara. The data was collected through interview and observation with triangulation data analysis techniques. The results of showed that teachers' performance in the digital era in improving learning quality are better. As a model by way of learning and teaching in the digital era, the teachers, among others (1) have the ability to collaborate with students, peers and communities in the use of digital sources. (2) Teachers have the ability to build networks and (3) have a sense of social responsibility. (4) Teachers have a discipline of time and are proficient in using technology. (5) Teachers are more at ease in preparing learning tools in the digital era. (6) Teachers are more creative and innovative in teaching and learning. Conclusion is Teacher Performance in planning, implementation and evaluation to improve the quality of learning has been running optimally.
\end{abstract}

Keywords: Teacher Performance, Digital Era, Learning Quality

\section{Introduction}

In the Digital Era teachers are required to develop professionalism in accord with the development of time, science and technology, and the needs of society. Professional teachers should be able to understand the components of applicable educational concepts so as to understand the foundation and education policy, the development level of learners and learning approaches in accordance with the learning materials. The success of learning is determined by the teaching methods and learning media (Ali, 2009). Through the use of assistive devices in the form of media, there is hope of increased communication relations for it to be able to run smoothly with maximum results (Taufiq et al., 2014). Learning outcomes are abilities that students have from the learning process that are influenced by internal and external factors (Mardiyan, 2012). Thus, in this digital era teachers are expected to have the ability to use technology, and there would transformation and creative power in the digital era, (Karakas \& Manisaligil, 2012). The creative power possessed by a teacher shows his/her performance, performance requires the interaction of reciprocity and cooperation to achieve teacher's task/performance (Ling Tung \& Hsuan Chang, 2011). Performance is a work ability shown by a person to achieve results
(Eros, 2014). It is identical to work achievement (Khodijah, 2013). Work performance is the result of work that is achieved by the employee in carrying out the tasks assigned to him (Rofi, 2012). The quality and value of performance depend on the ability of management to respond to needs or outcomes (McEwen, etc, 2010).

Performance is an achievement of a certain job quality requirements that can ultimately be directly reflected in the output or the quality produced, (Simamora, 2000). Output or the quality produced is related to the results of the work implementation which could be physical/material and non physical/non-material. Teacher performance, internally, is determined by competence, motivation, and high commitment in performing the task (Sudjana, 2012).

Associated with teacher performance in lesson planning, it is a professional duty of a teacher, but in fact many teachers do not do it. They often enter the classroom without planning because it is considered to be a repetitive work that is done every day with the same characteristics of learners each year, the same curriculum and teaching materials. This leads to a condition where teachers conduct the lesson according to what is remembered without paying attention to the competence level of the learners as they do not have previous learning evaluation 
results. Moreover, the learning process neglects the characteristics of the students. Therefore, teachers in the digital era need to improve their performance through various media technology in order to achieve the quality of learning in accordance with the purpose of learning. One of the learning objectives can be viewed through teacher performance.

The digital era has brought various forms of change, both positive and negative. Thus, it has become a new challenge for human in this digital era. Challenges in the digital era have entered various fields such as politics, economics, social culture, education and information technology itself. The digital era was born with the emergence of the digital internet network, especially computer information technology. The increasing advancement of today's digital technology is creating massive changes to the world, where the birth of various advanced digital technologies has emerged. Various circles have been facilitated in accessing information in many ways and are able to enjoy facilities freely and in control. If it can be appropriately applied in education, it would create power to improve the learning quality. Quality students are expected to have good knowledge at the end of their learning (Hay \& Kinchin, 2008). This shows the emphasize of e-learning quality framework of the quality of employees/teachers (Ireland, et al., 2009). Fresh ideas of training and service quality development must be possessed by educators for organizational progress (Smith \& Peter, 1998). The experience of quality teaching for adult students is a lifelong learning process (Kafafi, 2012).

According to Tilaar (2000), quality also means caliber that describes the overall satisfying characteristics in its use, free from deficiencies, where operationally it means something that has qualities that satisfy everyone. Moreover, Uwes (2009: 27) explains that substantively the term quality itself contains two things, namely (1) nature, which is something that explains the state of the object, (2) level, which indicates its position in a scale. On the contrary, learning is a process toward the achievement of educational goals. In this case, learning process is very important in determining where the students will be taken because learning process is an integral part of education, (Usmanto, 2012).

\section{Method}

The method used in this research used was qualitative research method involving 12 informants as teacher representatives who are teaching at SMA N 12 Kupang City, East Nusa Tenggara. The data was collected through interview and observation with triangulation data analysis technique.

\section{Results and Discussion}

Based on the objective of the research which aims to determine the performance of teachers in the digital era in improving learning quality, then one of the indicators of teacher performance is teachers' performance in lesson planning including making reports (annual, semester), details of its effective weeks, the minimum mastery criteria (KKM), syllabus, lesson plans (RPP), and assessment system plan.

In accordance with the indicators above, every teacher in the State High Schools of Kupang City, based on the interview results, is considered to be able to create good programs (annual, semester) and other learning tools. The teachers interview result (US, EL) shows that lesson planning is done twice every year, and it begins with making the yearly semester program and other learning tools in accordance with the needs of the school. The activity is carried out before learning activities begins (done at the beginning of the semester). The results of interviews with teachers (YM, RH, RM) explain that once creating annual and semester programs as well as lesson plans are finished, the teachers then collectively determine the Minimum Mastery Criteria (KKM) embracing both the level of difficulty and the level of ease. A teacher (IL) explained that teachers will prepare all the learning tools when they receive the information of supervision activities carried out by the school superintendent. This is shown in the corresponding observation result where there were some teachers who only used handbook during teaching and learning process without bringing any supporting learning tools. However, there are teachers who said that it was easier for them to prepare learning tools in the digital era because it makes teachers more creative and innovative in teaching and learning.

According to the interview results with teachers (RI, YY), within the implementation of teaching, teachers are discipline in entering the classroom and providing learning materials in accordance with the applicable curriculum based on competencies that have been prepared in the 
syllabus and Lesson Plan. An interview with teacher $(\mathrm{AB})$ mentioned that there were teachers who came to class and gave the students tasks and instructed the student to take notes (dictation) from the existing package book. However, some teachers have the ability to collaborate with students, peers and communities in the use of digital resources, teachers have the ability to build networks. This is supported by the observation results that teachers used the WhatsApp application to communicate with students to give information of tasks and other.

Based on the results of interviews with teachers (RM, WM, OL), it is revealed that the implementation of the learning evaluation in State Senior High Schools in Kupang City is in accordance with the evaluation plan that has been determined both for the evaluation of the final semester examination, midterm examination, daily tests, and assignments. If the implementation of the learning evaluation of the learners did not achieve the indicator of the defined mastery criteria, remedial will be done once or twice. However, based on the findings in the field, it was found that the learning evaluation was still less effective due to teachers who were still conducting a sudden test without first notifying the learners. Therefore, teachers are expected to have the discipline of time and the proficiency in the use of technology to ease them in doing evaluations.

Based on the results of the research above, the performance of teachers' lesson planning in the digital era in has been implemented effectively as a whole. It is clear that the teachers at State Senior High School in Kupang City, East Nusa Tenggara, aimed their entire lesson plan based on the demands of the existing curriculum. The book of the 21st Century Personnel Education System Development by the Department of Education and Culture stated that teachers should construct the policy and the foundation of education in the form of lesson plan and applying the learning components as a system in the learning process. Nevertheless, the facts in the field which are based on the results of observations and documents, found that there were still teachers who were only planning when they were going to be supervised. As a matter of fact, the lesson plan was still very conventional where it does not use online media for learning materials and learning tools so it can be easily accessible by learners. Teachers need to spend a lot of time in preparing the lesson plan because lesson plans need to be adjusted with the teacher's situation, for example the students profile and the facilities owned by the teachers (Saad \& Dawson, 2018). Lesson planning includes role play of characters to understand more learning approaches (Bestwick, 2017), therefore lesson planning must be discussed together in a group discussion of the subject teachers (Chichibu, 2016).

Based on the results of the research above, the performance of teachers in the digital era in the implementation of learning process in State High Schools in Kupang-East Nusa Tenggara took place efficiently, starting by giving the teaching materials, assignments, conducting discussions (question and answer) in the class as a whole which can be stated as good. However, based on observations in the field, there were teachers in the learning process who did not provide opportunities for students to ask. The teacher simply read and explained what is missing in the book without providing further explanation with the support of references from other sources related to the teaching materials. However, teachers should have better skills and characteristics in this 21 st century. This is supported by the research of (Sudirman \& Bokingo, 2017) that teachers must have characteristics, proficiency and skills in the 21st century. The learning process or the results as evaluation is used by teachers to gather information, analyze and interpret it, infer, make wise decisions and take appropriate actions in the service of improving teaching and learning (Berry, 2008). Students realize that the more specific they understand the lesson the better the results are obtained (Dubicki, 2015). The implementation of learning is the identification of students' needs, the application of the learning programs, the assessment of the process and the results and impacts of which there is a learning experience that students obtain (Katiah, 2017).

From the results of the research revealed above, the performance of teachers in the learning evaluation of State High Schools in Kota Kupang-East Nusa Tenggara as a whole was implemented efficiently and effectively both in scheduling exams and determining the level of difficulty and easiness in the preparation of exam questions for learners. If there were learners who did not achieve the established mastery of each subject, then the teacher will provide remedial. However, there were still teachers who conducted the evaluation without 
notifying the exam schedule and learners' test results were not returned thus learners could not know to which extent they have understood the material's mastery. Evaluation is a systematic assessment of the program or policy results to increase improvements (Nien Chen, 2006). It is a form of responsibility in defining good practices or determining the results of work, and the function of learning and evaluation development (Cooper, 2014). The learning evaluation process carried out by the teacher when giving an assessment for students' learning outcomes is only guided by the set of answer keys and assesses students' answers to right or wrong. It is rare for teachers to evaluate by observing the attitude of students when reading or answering questions in the problem (Pratiwi \& Setyarsih, 2015).

\section{Conclusion}

The conclusions from the teacher performance in the digital era in improving the learning quality concludes that teachers' performance in lesson planning has not been done maximally, this is because there are still teachers who have not prepared the learning tools in teaching. Hence, teachers need to do prepare for their lessons, the learning process in the digital era can be said to be good, but improvements are needed for example teachers are able to conduct online assignment for students via email, wheres the performance of teachers in learning evaluation of State High Schools in Kupang has been running optimally, whether it is for the semester final exam, midsemester exam, assignments and daily tests, it all goes well. Nonetheless an upgrade into a more modern way of evaluation is needed by conducting online assessments such as exams via email and so on. The implications of this study contribute to the development of literature and also to the development of teacher's insight regarding technology in the digital era and the benefits of technology for learning.

\section{References}

Ali, Muhamad (2009) "Development of Interactive Learning Media Electromagnetic Media Courses". JurnalEdukasi@elektro, Vol. 5(1), 1118.

Bestwick, Angel Margaret (2017) "Beatrix Potter and Her Paint Box Lesson Plan". Social Studies Research and Practice, Vol. 12(2), 232-242.
Berry, R. (2008), Assessment for Learning, Hong Kong University Press, Hong Kong, Vol. 1,4-13.

Chichibu, Toshiya (2016) "Impact on Lesson Study for Initial Teacher Training in Japan". International Journal for Lesson and Learning Studies, Vol. $5(2), 155-168$.

Cooper, Sue (2014) "Transformative Evaluation Organisational Learning Through Participative

Practice". The Learning Organization, Vol. 21(2), 146-157.

Dubicki, Eleonora (2015) "Writing a Research Paper Student Explain Their Process". Reference Service Review, Vol. 43(4), 673-688.

Eros, Endy (2014) 'Effect of Teachers' Motivation and Dicipline on Their Performance as Teachers of State Junior High School in Brebes Sub District, Central Java. Jurnal Administrasi Publik dan Birokrat, Vol. 1(1)

Hay, David \& Kinchin, Ian (2008) “ Using Concept Mapping to Measure Learning Quality". Journal Education and Training, Vol. 50(2), 167-182.

Ireland, Jennifer.et.al (2009) "Developing Quality in E-learning: A Framework in Three Parts". Journal Quality Assurance in Education, Vol. 17(7), 250-263.

Kafafi, El. Siham (2012) "Assesment the Road to Quality". Word Journal of Science, Technology and Sustainable Development, Vol. 9(2), 99-107.

Karakas, Fahri \& Manisaligil, Alperen (2012) "Reorienting Self-Directed Learning For The Creative Era". Europan Journal of Training and Development Vol.36(7), 712- 731

Katiah, (2017) "The Learning Process Cooperation Academic Education Program (Co-op) in Increasing Student Independence. Educational Journal UPI: Bandung

Khodijah, Nyanyu (2013) "Performance of Madrasah Teachers and PostCertification Islamic Religious Education Teachers in South Sumatra". Cakrawala Pendidikan Journal, Vol 32(1)

Ling Tung, Hiu \& Hsuan Chang, Yu (2011) 
"Effects of Empowering Leadership on Performance in Management Team" Journal of Chinese Human Resource Management, Vol.2(1), 43-60.

Mardiyan, Riry (2012) "The Increase of Student Activity and Learning Outcomes in Learning Accounting for Adjustment Journal Material in Grade XI Science Students of Bukit Tinggi State High School using the Method of Role Playing". Education Specialist Journal, Vol.10(2)

McEwen, Jesicca. et.al (2010) "Reflective Practice Embedding Outcomes Recording in Barnardo's Performance Management Approach". International Journal of Productivity and Performance Management, Vol. 59(6), 786-598.

Nien Chen, Kuan (2006) "Institusional Evaluation and its Influence on Organizational Learning". Aslib Proceeding New Information Perspectives. Vol.59(1), 5-25.

Pratiwi, Nurul Dwi \& Setyarsih, Woro. (2015). Development of Taxonomy Based Evaluation of the Structure of the Observed Learning Outcome (SOLO) Instrument to Determine Students' Profile in the Ability to Solve Static Fluid Problems. Journal of Physics Education Innovation (JIPF) Vol. 04(03), 45-49 ISSN: 2302-4496.

Rofi, Nur Ahmad (2012) "The Influence of Work Discipline and Work Experience on Employee Work Performance at the Production Department of PT Leo Agung Raya Semarang". Journal of Management Science and Applied Accounting, Vol. 3(1)

Saad, Aslina \& Dawson, Christian (2018)
"Requirement Elicitation Techniques for an Improved Case Based Lesson Planning System". Journal of System and Information Technology, Vol. 29(1), 19-32.

Simamora, Henry (2000) "Business Decision Making Principles". Salemba Empat. Jakarta. I

Smith, Peter.A.C \& Peters, John (1998) "Techniques Learning About Service Quality". Journal Managing Service Quality, Vol.8(2), 119-125.

Sudjana, Nana. (2012) "Evaluation of Teaching and Learning”. Bandung: Remaja Rosda Karya

Sudirman \& Agus Hakri Bokingo (2017) "Teacher of The Year: Teacher Performance in the Frame of 21st Century Education Development.”. An Article form the Second National Seminar of Advancing and Exciting Education// Accessed on 08/07/2018

Taufiq, M. et.al (2014) "Development of Integrated Science Learning Media with Environmental Care Characteristics of 'Conservation' Themes Approaching Science-Edutainment". Science Education Journal/Unnes.ac.id., Vol. $3(2)$

Tilaar, H.A.R. (2001) "National Education Standardization, A Review". Tera: Jakarta

Uwes, Sanusi (2009) "Lecturer Development Management.”. Logos Wacana Ilmu: Jakarta

Usmanto. A Paper on and Learning and Teaching in Islamic Religious Education // accessed on 20/07/2018

Teachers and Lecturers Regulation No. 14 Year 2005 on Teacher Qualification and Competency Standards. 